\title{
Activation of nitrate reductase of cashew leaf by exogenous nitrite
}

\author{
Ricardo Almeida Viégas ${ }^{1}$ and Joaquim Albenísio Gomes Silveira ${ }^{2, *}$ \\ ${ }^{1}$ Departamento. de Engenharia Florestal, Universidade Federal da Paraíba, Campus VII, CP 64, CEP 58700-970, Patos, PB, Brasil; \\ ${ }^{2}$ Departamento de Bioquímica e Biologia Molecular, Universidade Federal do Ceará, CP 6020, CEP 60451-970, Fortaleza, CE, Brasil; \\ *Corresponding author: silveira@ufc.br
}

Nitrate reductase (NR) plays a central role in plant primary metabolism and exhibits complex regulation mechanisms for its catalytic activity. There is controversy in the literature concerning the possible direct effect of $\mathrm{NO}_{2}^{-}$on the stimulation and/or activation of NR activity. The influence of $\mathrm{NO}_{2}{ }^{-}$was studied on the NR activity in the leaves of 30-day-old cashew (Anacardium occidentale L.) seedlings. Addition of $\mathrm{NO}_{2}{ }^{-}$to the reaction mixture containing leaf enzymatic extract resulted in a remarkable increase in NR activity. A trace amount $\left(5 \mu\right.$ mol. $\left.\mathrm{L}^{-1}\right)$ of $\mathrm{NO}_{2}^{-}$was required to achieve full NR activity. The in vitro $\mathrm{NR}$-activity showed a steady time-dependent increase when incubated in the presence of only $\mathrm{NO}_{3}^{-}+\mathrm{NO}_{2}^{-}$. In contrast, in vitro $\mathrm{NR}$ activity was practically absent in a $\mathrm{NO}_{2}^{-}$-free reaction medium, even in the presence of a saturating $\mathrm{NO}_{3}{ }^{-}$concentration. No oxidation of $\mathrm{NO}_{2}{ }^{-}$to $\mathrm{NO}_{3}{ }^{-}$was detected during the experiment. Although $\mathrm{NO}_{2}{ }^{-}$clearly activated the in vitro NR activity, it had no effect on the in vivo leaf-NR activity determined under absence of oxygen. NADH at concentrations greater than $0.5 \mathrm{mmol} . \mathrm{L}^{-1}$ decreased the rates of in vitro NR activity. These results indicated, at least partially, a strong cashew leaf $\mathrm{NO}_{2}{ }^{-}$dependency of NR activation and/or activity. Finally, based on these results, it is suggested that this singular NR activity model induced by exogenous $\mathrm{NO}_{2}{ }^{-}$in cashew leaf extracts is caused by changes in the NR activation state by $\mathrm{NO}_{2}{ }^{-}$itself.

Key words: Anacardium occidentale, enzymes, NADH, nitrate metabolism, nitrate reductase.

Ativação de redutase de nitrato de folhas de cajueiro por $\mathrm{NO}_{2}^{-}$exogéno: $\mathrm{O}$ efeito do $\mathrm{NO}_{2}^{-}$sobre a atividade de $\mathrm{RN}$ foi estudado em folhas de plantas jovens de cajueiro, com 30 dias de idade, cultivadas em solução nutritiva. A atividade in vitro de NADH-RN aumentou com a presença de $\mathrm{NO}_{2}{ }^{-}$no meio de reação. Este aumento foi máximo em presença de 5,0 $\mu$ mol.L $L^{-1}$ de $\mathrm{NO}_{2}^{-}$. Com a remoção de $\mathrm{NO}_{2}^{-}$, do meio de reação, a atividade de $\mathrm{RN}$ foi praticamente suprimida, apesar da presença de $\mathrm{NO}_{3}{ }^{-}$em concentração em nível de saturação da enzima. Este fato, ao menos em parte, sugere uma certa dependência da $\mathrm{RN}$, por $\mathrm{NO}_{2}{ }^{-}$, para redução de $\mathrm{NO}_{3}{ }^{-}$. Muito embora o $\mathrm{NO}_{2}{ }^{-}$tenha sido necessário para a ativação in vitro de $\mathrm{RN}$, este íon não foi capaz de produzir o mesmo efeito sobre a atividade de $\mathrm{RN}$ in vivo, quando o mesmo foi acrescido ao meio de reação contendo discos de folhas sob anaerobiose. A atividade de RN in vitro foi proporcionalmente dependente do tempo de incubação na presença de $\mathrm{NO}_{3}{ }^{-}+\mathrm{NO}_{2}{ }^{-}$. Com relação à concentração de $\mathrm{NADH}$, a atividade de $\mathrm{RN}$ apresentou saturação com $0,50 \mathrm{mmol} . \mathrm{L}^{-1}$ de NADH e um discreto decréscimo a partir dessa concentração. Finalmente, os resultados do presente estudo sugerem que o $\mathrm{NO}_{2}{ }^{-}$induziu a atividade de $\mathrm{RN}$, em extratos de folhas de plantas de cajueiro, possivelmente, por causar mudanças no estado de ativação da enzima.

Palavras-chave: Anacardium occidentale L., assimilação do nitrato, NADH, enzima, redutase do nitrato.

\section{INTRODUCTION}

Nitrate is the major $\mathrm{N}$-source for cultivated plants and is an important signaling ion that influences plant growth and differentiation (Kaiser and Huber, 2001). Nitrate assimilation represents a central point in the growth of plants and other organisms (Silveira et al., 2001a). The utilization of $\mathrm{NO}_{3}{ }^{-}$by higher plants involves its reduction to $\mathrm{NH}_{4}^{+}$in a two-step pathway and the incorporation of
$\mathrm{NH}_{4}^{+}$to skeletons of carbon to produce amino acids (Galván et al., 1992; Viégas et al., 1999). The reduction of $\mathrm{NO}_{3}^{-}$to $\mathrm{NO}_{2}{ }^{-}$is a limiting step catalyzed by nitrate reductase -NR (Silveira et al., 2001b). NR is a most interesting enzyme especially from the aspect of its complex regulation expression and control of catalytic activity. NR requires NADH as electron donor in most higher plant species (Kaiser and Huber, 2001). 
NR enzyme is a complex molecule containing FAD, Cyt $b$ 557, and a Mo-Co as prosthetic groups. In higher plants, NR exists as a homodimer with a subunit molecular mass of 100 to $120 \mathrm{kDa}$ (Campbell, 1999). In addition, NR is regarded as one of the best-characterized examples of substrate-induced enzyme in higher plants (Adrews et al., 1990). NR is subject to mechanisms controlling its gene induction and expression and catalytic activity (Haba et al., 2001). In most plant species, for instance, NR is specifically induced by $\mathrm{NO}_{3}^{-}$while nitrite reductase (NiR) synthesis is enhanced by both $\mathrm{NO}_{3}^{-}$and $\mathrm{NO}_{2}^{-}$(Aguera et al., 1990).

Aslam et al. (1987) reported that barley leaf NR activity was induced by nutrient solution- $\mathrm{NO}_{2}^{-}$, but a much higher concentration of external $\mathrm{NO}_{2}{ }^{-}$than $\mathrm{NO}_{3}{ }^{-}$was required for induction. According to these authors, there was no induction with $\mathrm{NO}_{2}{ }^{-}$until tissue- $\mathrm{NO}_{3}{ }^{-}$appeared, apparently from the internal oxidation of $\mathrm{NO}_{2}^{-}$. In contrast, Siddiqui et al. (1992) reported that external- $\mathrm{NO}_{2}{ }^{-}$pretreatment was not able to induce NR activity in barley seedlings. The appearance of $\mathrm{NO}_{3}{ }^{-}$from the oxidation of $\mathrm{NO}_{2}{ }^{-}$ into tissue is well established (Lips et al., 1973; Kaplan et al., 1974; Sahulka and Lisa, 1978; Aslam and Huffaker, 1989; Aslam et al., 1993). However, it is still uncertain whether $\mathrm{NO}_{2}{ }^{-}$oxidation in the cell is a chemical or biochemical process. Aslam et al. (1993) observed that NR induction by both $\mathrm{NO}_{2}{ }^{-}$and $\mathrm{NO}_{3}{ }^{-}$was inhibited by cycloheximide, indicating that the increase in NR activity was a result of increased NR synthesis rather than the activation of preexisting NR protein.

Since $\mathrm{NO}_{2}{ }^{-}$is oxidized to $\mathrm{NO}_{3}{ }^{-}$in the cell and the latter is an NR substrate, it is difficult to determine whether $\mathrm{NO}_{2}{ }^{-}$plays any role directly in NR activation, i.e., before it has been oxidized to $\mathrm{NO}_{3}^{-}$. In vitro studies involving $\mathrm{NR}$ enzyme should be carried out to overcome this difficulty. Aslam et al. (1993), for instance, could not detect any in vitro activation of NR activity by $\mathrm{NO}_{2}{ }^{-}$. To our knowledge, only Kaplan et al. (1978) reported in vitro activation of NR activity by $\mathrm{NO}_{2}^{-}$. They found that the $\mathrm{NR}$ induced by $\mathrm{NO}_{3}^{-}$ and the $\mathrm{NR}$ activated by $\mathrm{NO}_{2}{ }^{-}$are different and the molecular mass of the $\mathrm{NO}_{2}{ }^{-}$activated-NR is lower than that of $\mathrm{NO}_{3}{ }^{-}$ NR. They also postulated that the potential NR-component that could be activated by $\mathrm{NO}_{2}{ }^{-}$is a constitutive subunit that becomes incorporated into the NR protein during the Cyt $\underline{\mathrm{c}}$ synthesis.

In the present study, it was shown that cashew seedling leaf NADH-NR was directly activated by exogenous
$\mathrm{NO}_{2}^{-}$. It is suggested that the changes in the NR activation state in cashew leaves are rapidly and effectively controlled by $\mathrm{NO}_{2}{ }^{-}$at very low tissue concentrations.

\section{MATERIAL AND METHODS}

Plant growth conditions: Dwarf cashew seeds (Anacardium occidentale L.) supplied by Embrapa, Fortaleza, Brazil, were surface-sterilized in $1 \%(\mathrm{v} / \mathrm{v})$ hypochlorite solution for $15 \mathrm{~min}$, rinsed in distilled water and imbibed for $12 \mathrm{~h}$. The seeds were subsequently sown in vermiculite and watered daily with a solution containing $1.0 \mathrm{mmol} . \mathrm{L}^{-1} \mathrm{CaSO}_{4}$ (Viégas and Silveira, 1999). Ten days after sowing, seedlings selected by similar height were placed in plastic pots $\left(1.0 \mathrm{dm}^{3}\right.$ capacity) filled with continuously air bubbled modified half-strength Hoagland and Arnon nutrient solution with the following composition $\left(\mathrm{mmol} . \mathrm{L}^{-1}\right): 2.0, \mathrm{KNO}_{3}$; 1.5, $\mathrm{Ca}\left(\mathrm{NO}_{3}\right)_{2} ; 0.5, \mathrm{CaCl}_{2} ; 0.5, \mathrm{MgSO}_{4} ; 0.5, \mathrm{~K}_{2} \mathrm{HPO}_{4}$; and micronutrients. After 10 days, the ionic strength of the nutrient solution was twofold increased. The plants were grown under greenhouse conditions, exposed to natural sunlight and day/night temperature means of $32 / 23{ }^{\circ} \mathrm{C}$ and $60 / 80 \%$ relative humidity. The nutrient solution was completely changed every day and the $\mathrm{pH}$ maintained at $5.5 \pm$ 0.5. Leaf discs were collected from the second youngest fully expanded leaves, as described by Viégas et al. (1999), to evaluate the in vivo NR activity when the homogeneous plant population was 30 days old. At this time, other second youngest fully expanded leaves were excised, immediately frozen in liquid $\mathrm{N}_{2}$, ground to a fine powder, and stored at $-80^{\circ} \mathrm{C}$ until determination of the in vitro $\mathrm{NR}$ activity.

In vitro NR assay: Frozen leaf was homogenized in an extraction medium $\left(6.0 \mathrm{ml} . \mathrm{g}^{-1}\right.$ fresh mass, at $4{ }^{\circ} \mathrm{C}$, for $\left.5 \mathrm{~min}\right)$ with a pestle and mortar. The extraction medium consisted of 100 mmol.L $\mathrm{L}^{-1}$ Tris-HCl buffer (pH 7.6) containing EDTA$\mathrm{Na}^{+}\left(5 \mathrm{mmol} . \mathrm{L}^{-1}\right)$, polivinypolypyrrolidone $(5 \%, \mathrm{w} / \mathrm{v})$, casein $(1.5 \%, \mathrm{w} / \mathrm{v})$ and $\beta$-mercaptoethanol $\left(5 \mathrm{mmol} . \mathrm{L}^{-1}\right)$. The homogenate was centrifuged at $20,000 g_{n}$, for $20 \mathrm{~min}$ at $4{ }^{\circ} \mathrm{C}$, and then filtered through two layers of cheesecloth. The supernatant was collected for evaluation of the in vitro leaf-NR activity as previously described (Viégas et al., 1999). The reaction mixture contained $100 \mathrm{mmol}^{-\mathrm{L}^{-1}}$ Tris$\mathrm{HCl}$ buffer $\mathrm{pH} 7.5$; NADH was supplied at $0.5 \mathrm{mmol} . \mathrm{L}^{-1}$, $40 \mathrm{mmol} . \mathrm{L}^{-1} \mathrm{KNO}_{3}$; and the presence $\left(+\mathrm{NO}_{2}{ }^{-}\right)$or absence $\left(-\mathrm{NO}_{2}{ }^{-}\right)$of $5.0 \mu \mathrm{mol} . \mathrm{L}^{-1} \mathrm{KNO}_{2}$ in a final volume of $1.2 \mathrm{~mL}$. 
Then $0.25 \mathrm{~mL}$ of leaf crude extract was added to the reaction mixture and incubated at $35{ }^{\circ} \mathrm{C}$ for $15 \mathrm{~min}$. The mixtures were previously and vigorously shaken to ensure thorough mixing. After centrifuging, a supernatant sample was taken to determine $\mathrm{NO}_{2}{ }^{-}$concentration.

In vivo NR assay: The in vivo NR activity was assessed by the "anaerobic tissue slice method" described by Silveira et al. (1998). Leaf discs from the second youngest fully expanded leaves ( $200 \mathrm{mg}$ fresh mass, $10 \mathrm{~mm}$ diameter) were collected $4 \mathrm{~h}$ after the beginning of the natural light period (10:00 a.m.) and infiltrated twice for $2 \mathrm{~min}(-67 \mathrm{kPa}$ vacuum) with $5 \mathrm{~mL}$ of a reaction mixture containing 100 mmol. $\mathrm{L}^{-1}$ potassium phosphate buffer $\mathrm{pH} 7.5 ; 25$ mmol. $\mathrm{L}^{-1}$ $\mathrm{KNO}_{3}$; and $1 \%$ iso-propanol. The reaction mixture was incubated at $35{ }^{\circ} \mathrm{C}$ for $30 \mathrm{~min}$ in the dark. NR activity was estimated from the amount of $\mathrm{NO}_{2}^{-}$formed during the incubation period and released from the leaf discs to the medium after boiling for $5 \mathrm{~min}$. Aliquots were mixed with $2 \mathrm{~mL}$ of (1:1) $1 \%$ sulfanilamide in $\mathrm{HCl} 2.4$ mol. $^{-1}$ : $0.02 \%$ $\mathrm{N}$-1-naphtyl-ethylenediamine and the absorbance determined at $540 \mathrm{~nm}$. Five independent replications were used in all the enzymatic assays.

\section{RESULTS AND DISCUSSION}

Figure 1 shows that in vitro NR activity measured in crude leaf extract exposed to $25 \mathrm{mmol} . \mathrm{L}^{-1} \mathrm{NO}_{3}^{-}$in absence of $\mathrm{NO}_{2}^{-}$continued unchanged at the indicated times. In contrast, when the same crude leaf extracts were measured in the presence of both $5 \mu \mathrm{mol} . \mathrm{L}^{-1} \mathrm{NO}_{2}{ }^{-}$and 25 mmol. $\mathrm{L}^{-1} \mathrm{NO}_{3}^{-}$, the NR activity was greatly increased in relation to the reaction time. It is suggested that the joint action of $\mathrm{NO}_{2}{ }^{-}$and $\mathrm{NO}_{3}{ }^{-}$on $\mathrm{NR}$ activity may represent a specific rather than a general rule. NR activity assayed in the presence of $5 \mu \mathrm{mol} . \mathrm{L}^{-1} \mathrm{NO}_{2}{ }^{-}$reflected the maximum activity observed in the assay (data not shown). The absence of any lag period in the NR activity along the course of the assay (figure 1) suggests that $\mathrm{NO}_{2}^{-}$directly activated NR. In addition, the linear rate $\left(\mathrm{r}^{2}=0,9917^{* *}\right)$ of $\mathrm{NO}_{2}^{-}$formation during the $\mathrm{NR}$ assay, in the presence of $\mathrm{NO}_{2}^{-}$, ensured a sufficient supply of NADH to the reaction. In fact, our experiments had shown that $0.5 \mathrm{mmol} . \mathrm{L}^{-1} \mathrm{NADH}$ was required to achieve the maximum effect of $\mathrm{NO}_{2}^{-}$on the NR activity (figure 2). The overall results showed, initially, a clear stimulating effect of the short-term treatment with $\mathrm{NO}_{2}{ }^{-}$on the in vitro $\mathrm{NR}$ activity.

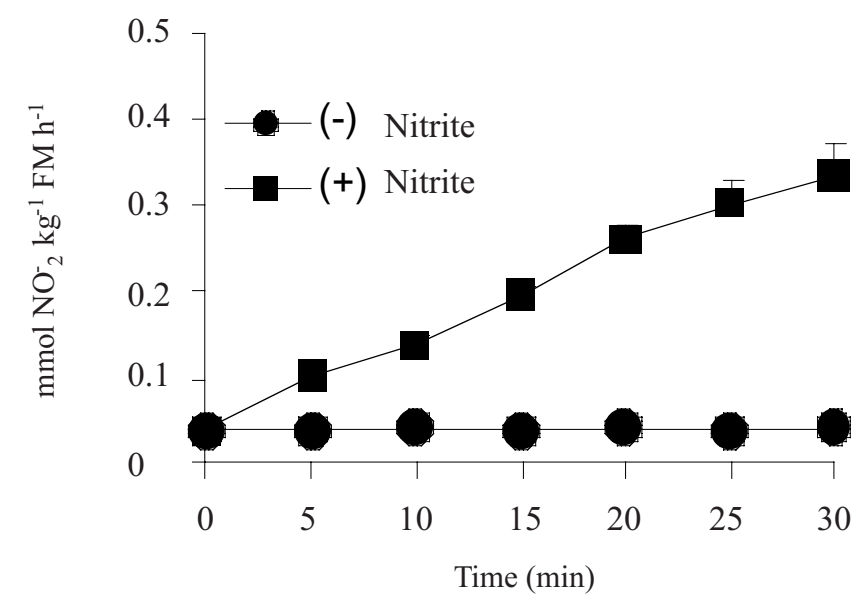

Figure 1. Time course of NR activity in cashew leaves. NR activity was assayed in the absence (-) or presence $(+)$ of $5 \mu \mathrm{mol} . \mathrm{L}^{-1} \mathrm{NO}_{2}^{-}$in a buffered reaction medium containing 25 mmol. $\mathrm{L}^{-1} \mathrm{NO}_{3}^{-}$and $\mathrm{NADH}$ as electron donor. The $\mathrm{NO}_{2}^{-}$concentration supplied to the mixture was corrected for the $\mathrm{NO}_{2}^{-}$formed during the assay. The points are means of five independent replicates. Bars represent $\pm \mathrm{SD}$ when larger than the symbols.

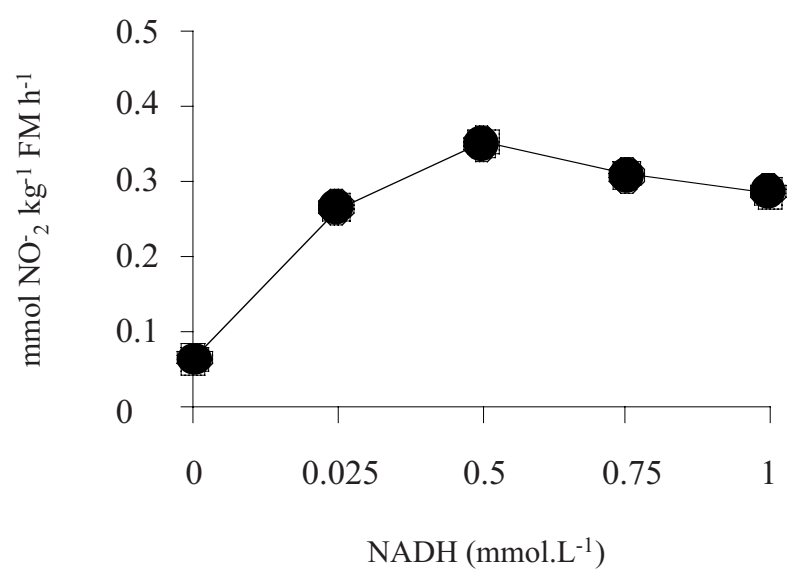

Figure 2. In vitro NR activity in cashew leaves in response to NADH concentration. The NR activity was assayed in a buffered reaction medium containing $5 \mu \mathrm{mol} \cdot \mathrm{L}^{-1} \mathrm{NO}_{2}{ }^{-}$and 25 mmol. $\mathrm{L}^{-1} \mathrm{NO}_{3}^{-}$. The $\mathrm{NO}_{2}^{-}$supplied to the mixture was corrected for the $\mathrm{NO}_{2}^{-}$formed during the assay. The points are the means of five independent replicates. Bars represent \pm SD when larger than the symbols.

There are conflicting reports in the literature on the induction and activation of $\mathrm{NR}$ by $\mathrm{NO}_{2}^{-}$. The fact that $\mathrm{NO}_{3}^{-}$ appears in the tissues of a number of plant species through internal $\mathrm{NO}_{2}{ }^{-}$oxidation, when the latter is the $\mathrm{N}$-sole source 
in the root growth medium (Lips et al., 1973; Kaplan et al., 1974; Aslam et al., 1987; Aslam and Huffaker, 1989; Aslam et al., 1993), strongly limits any conclusion on the direct induction and/or activation of the NR enzyme by $\mathrm{NO}_{2}^{-}$. In the current study, however, it was observed that leaf-NR activity in cashew plants was directly dependent on the presence of $\mathrm{NO}_{2}^{-}$in the reaction medium (figure 1). This result provides evidence for the possible occurrence of a $\mathrm{NO}_{2}^{-}$-actived NR state. Conversely, Aslam et al. (1993) were not able to detect any $\mathrm{NO}_{2}{ }^{-}$activated barley $\mathrm{NR}$ under in vitro conditions. On the other hand, Kaplan et al. (1978) observed an in vitro activation of $\mathrm{NR}$ by exogenous $\mathrm{NO}_{2}^{-}$. To our knowledge, cashew is the first plant species in which the presence of $\mathrm{NO}_{2}^{-}$in the reaction medium was required to in vitro activate $\mathrm{NR}$. It seems that $\mathrm{NO}_{2}^{-}$and $\mathrm{NO}_{3}^{-}$ions share different binding sites of leaf NR in cashew, but it is acknowledged that further study is necessary to confirm this hypothesis. It is suggested that $\mathrm{NO}_{2}^{-}$might change NR to a more active state.

NR is subjected to several mechanisms controlling both its synthesis and catalytic activity (Campbell, 1999). Some of the post-translational mechanisms are very well and/or still poorly established. Furthermore, besides $\mathrm{NO}^{-3}$ (NR substrate), $\mathrm{NO}_{2}{ }^{-}$and several organic nitro-compounds have been shown to induce NR in rice seedlings (Shen, 1972), but the inherent mechanisms are not clearly understood. Thus, $\mathrm{NO}_{2}^{-}$might be acting as a positive modulator, changing the NR activation state. It is also possible that $\mathrm{NO}^{-2}$ activates in vitro NR by changing its posphorylation state. One line of evidence in support of this suggestion is that cashew leaf activity leveled off in the absence of $\mathrm{NO}_{2}^{-}$ NR (figure 1). In cucumber, for instance, anoxia, uncouplers, and mannose feeding activate NR, at least by enhancing NR dephosphorylation via a decrease in the internal level of adenine nucleotides and a concomitant cellular acidification (Haba et al., 2001).

According to Kaplan et al. (1979), who observed direct $\mathrm{NR}$ activation by $\mathrm{NO}_{2}^{-}$, there is an $\mathrm{NO}_{2}^{-}$-actived component of NR that is a constitutive subunit that becomes incorporated into the NR protein during the synthesis of the Cyt $\underline{c}$ component. Additionally, there are some reports that showed the occurrence of an unidentified NR activated component (Kaplan et al., 1978). Shen (1972) proposed that NR-RNA and protein synthesis, which was associated with NR induction in radish cotyledons, might be required for the synthesis of an signal molecule necessary for NR activity. On the other hand, it was observed that very small changes of cytosol $\mathrm{pH}$ might induce changes in the NR activation state by mechanisms yet unknown (Kaiser and Huber, 2001).

The concentration of $\mathrm{NO}_{2}^{-}$that directly activates cashew leaf NR (figure 1) was substantially lower (by about 100 fold) than that required in the nutrient solution (Aslam et al., 1987). These authors reported that NR induction by environmental $\mathrm{NO}_{2}^{-}$was not observed until $\mathrm{NO}_{3}^{-}$was detected in the leaves of plants grown in $1.0 \mathrm{mmol} . \mathrm{L}^{-1} \mathrm{NO}_{2}^{-}$. They also showed that the quantitative relationship between internal $\mathrm{NO}_{3}{ }^{-}$concentration and the induction of $\mathrm{NR}$ was maintained irrespective of whether $\mathrm{N}$ was supplied as $\mathrm{NO}_{3}^{-}$ or $\mathrm{NO}_{2}^{-}$. According to Aslam et al. (1987), it can be concluded that $\mathrm{NO}_{2}^{-}$, due its internal oxidation to $\mathrm{NO}_{3}^{-}$, indirectly induced de novo synthesis of NR protein rather than the activation of the preexisting protein.

Evidence that the induction of $\mathrm{NR}$ activity by $\mathrm{NO}_{3}^{-}$ is regulated by enzyme synthesis rather than by an activation mechanism was also obtained by Somers et al (1983) and, more recently, by Kaiser and Huber (2001). According to Kaplan et al. (1978), however, the NR induced by $\mathrm{NO}_{2}{ }^{-}$and $\mathrm{NR}$ activated by $\mathrm{NO}_{2}{ }^{-}$are different, the latter protein presenting a comparatively lower molecular mass.

Since $\mathrm{NO}_{2}^{-}$oxidation to $\mathrm{NO}_{3}{ }^{-}$proceeds rapidly into the cell, there is no available information on a direct activation of NR after plants have been grown in the presence of external $\mathrm{NO}_{2}^{-}$. For instance, while $\mathrm{NO}_{2}^{-}$was not detected in detached leaves of 8-day-old barley seedlings placed in $1 \mathrm{mmol} . \mathrm{L}^{-1} \mathrm{NO}_{2}^{-}, 0.107 \mathrm{mmol} . \mathrm{kg}^{-1} \mathrm{NO}_{3}{ }^{-}$appeared in leaf tissue (Aslam et al., 1987). In the present study, analysis of the in vivo $\mathrm{NR}$ activity over time showed no $\mathrm{NO}_{2}^{-}$-dependent variations (figure 3 ). Similarly, in the study by Siddiqui et al. (1992), the in vivo NR activity was almost absent $\left(0.003 \mu \mathrm{mol} \mathrm{NO} \mathrm{NO}_{2}^{-} \cdot \mathrm{g}^{-1}\right.$ fresh wt.h $\left.{ }^{-1}\right)$ in the leaves of barley plants supplied with $0.1 \mathrm{mmol} . \mathrm{L}^{-1} \mathrm{NO}_{2}^{-}$for one day. They pointed out that $\mathrm{NO}_{2}^{-}$was unable to induce in vitro leaf $\mathrm{NR}$ activity, although $\mathrm{NO}_{3}{ }^{-}$accumulation in the leaf tissue $(2.70$ mmol. $\mathrm{kg}^{-1}$ fresh wt) was higher than in the study by Aslam et al (1987) (0.107 mmol. $\mathrm{kg}^{-1}$ fresh wt), who observed an in vitro induction of $\mathrm{NR}$ by environmental $\mathrm{NO}_{2}^{-}$.

These conflicting results on the in vitro induction of NR by external $\mathrm{NO}_{2}^{-}$in the studies of Aslam et al. (1987) and by Siddiqui et al. (1992) could be partially explained 
by the procedures they used in relation to NADH. Aslam and co-workers oxidized the NADH excess following the NR assay with phenazine methosulfate. In the present study, we observed that NADH interferes in the color formation in the $\mathrm{NO}_{2}^{-}$determination method (Figure 4). Thus, NADH concentration of $1.0 \mathrm{mmol} . \mathrm{L}^{-1}$ caused an overall $30 \%$ reduction in the $\mathrm{NO}_{2}{ }^{-}$concentration. Similar results were also described by Shen (1972). There was no attempt in this work to clarify the chemical mechanisms related to NADH interference on the reaction of the colored-complex formation after reaction between sulfanilamide, N-1-naphtyl-ethylenediamine and $\mathrm{NO}_{2}^{-}$.

The results shown in the present work are particularly interesting because they suggest that very low $\mathrm{NO}_{2}^{-}$ concentrations like those found in the plant cytosol might be able to activate NR, at least in cashew leaf tissue. Apparently, it is the first time that $\mathrm{NO}_{2}^{-}$has been shown to directly activate $\mathrm{NR}$, suggesting that $\mathrm{NO}_{2}^{-}$may play a crucial role in the modulation state of NR in cashew leaf. Nevertheless, proper interpretation of these results may be somewhat masked by the occurrence of no effect of $\mathrm{NO}_{2}^{-}$ on the in vivo NR activity, demanding further studies.

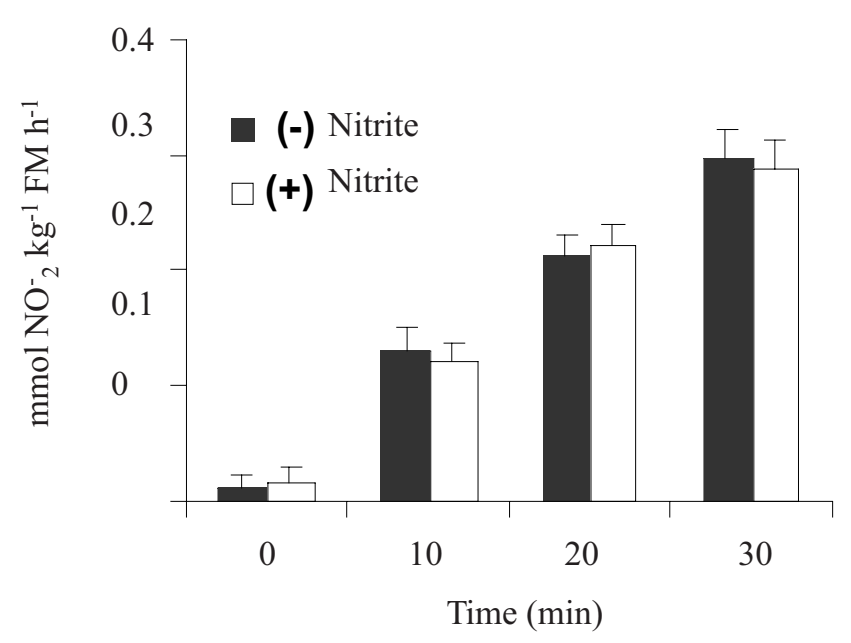

Figure 3. Time course of in vivo NR activity in cashew leaf discs. The NR activity was assayed in the absence $(-)$ or presence (+) of $5 \mu \mathrm{mol} . \mathrm{L}^{-1} \mathrm{NO}_{2}^{-}$in a buffered reaction medium containing $50 \mathrm{mmol} \cdot \mathrm{L}^{-1} \mathrm{NO}_{3}^{-}$. The $\mathrm{NO}_{2}^{-}$ supplied to the mixture was corrected for the $\mathrm{NO}_{2}^{-}$ formed during the assay. The time points are means of five independent replicates. Bars represent $\pm S D$ when larger than the symbols.

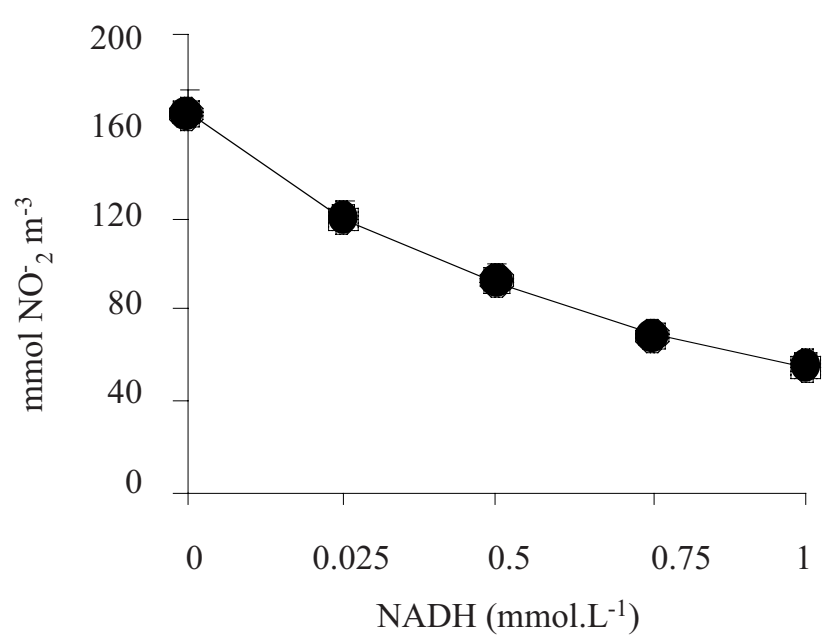

Figure 4. Effect of NADH concentration in the buffered reaction medium, in absence of enzymatic extract, on the intensity of diazonium salt formation (pink coloured complex, absorbance maximum at $540 \mathrm{~nm}$ ) from the reaction of the Gries's reagent with standard $\mathrm{KNO}_{2}$ solutions. The points are means of five independent replicates. Bars represent $\pm \mathrm{SD}$ when larger than the symbols.

Acknowledgements: The authors thank Conselho Nacional de Desenvolvimento Científico e Tecnológico (CNPq) and Fundação Cearense de Amparo à Pesquisa (FUNCAP) for funding this research.

\section{REFERENCES}

Adrews M, Faria SM, MCinroy GS, Sprent JI (1990) Constitutive nitrate reductase activity in the leguminosae. Phytochemistry 2:49-54.

Aguera E, Haba P, Fontes AG, Maldonado JM (1990) Nitrate and nitrite uptake and reduction by intact sunflower. Planta 182:149-154.

Aslam M, Rosichan J, Huffaker RC (1987) Comparative induction of nitrate reductase activity by nitrate and nitrite in barley leaves. Plant Physiol. 83:579-584.

Aslam M, Huffaker RC (1989) Role of nitrate and nitrite in the induction of nitrite reductase in leaves of barley seedlings. Plant Physiol. 91:1152-1156.

Aslam M, Travis RL, Huffaker RC (1993) Comparative induction of nitrate and nitrite uptake and reduction systems by ambient nitrate and nitrite in intact roots of barley (Hordeum vulgare L.) seedlings. Plant Physiol. 102:811-819. 
Campbell WH (1999) Nitrate reductase estructure, function and regulation: bridging the gap between biochemistry and physiology. Annu. Rev. Plant Physiol. Mol. Biol. 50:277-303.

Galván A, Cárdenas J, Fernández E (1992) Nitrate reductase regulates expression of nitrate uptake and nitrite reductase activities in Chlamydomonas reinhardtii. Plant Physiol. 98:422-426.

Haba P, Aguerra E, Benítez L, Maldonado JM (2001) Modulation of nitrate reductase activity in cucumber (Cucumis sativus) roots. Plant Sci. 161:231-237.

Kaiser WM, Huber SC (2001) Post-translational regulation of nitrate reductase: mechanism, physiological relevance and environmental triggers. J. Exp. Bot. 52:1980-1989.

Kaplan D, Roth-Bejerano N, Lips SH (1974) Nitrate reductase as a product-inducible enzyme. Eur. J. Biochem. 49:393-396.

Kaplan D, Mayer AM, Lips SH (1978) Nitrite activation of nitrate reductase in higher plants. Planta 138:205-209.

Kaplan D, Mayer AM, Lips SH (1979) Effect of cyanide and nitrite on the activity of nitrate reductase. In: Hewitt EJ, Cutting CV (eds), Nitrogen Assimilation of Plants v.1, pp.315-320. Academic Press, New york.

Lips SH, Kaplan D, Roth-Bejerano N (1973) Studies on the induction of nitrate reductase by nitrite in been seed cotyledons. Eur. J. Biochem. 37:589-592.

Sahulka J, Lisa L (1978) The influence of sugars on nitrate reductase induction by exogenous nitrate or nitrite in excised Pisum sativum roots. Biol. Plant. 20:359-367.
Shen TC (1972) Nitrate reductase of rice seedlings and its induction by organic nitro-compounds. Plant Physiol. 48:546-549.

Siddiqui MY, King BJ, Glass ADM (1992) Effects of nitrite, chlorate, and chlorite on nitrate uptake and nitrate reductase activity. Plant Physiol 100:644-650.

Silveira JAG, Matos JCS, Ceccato VM, Sampaio AH, Costa RCL, Viégas RA (1998) Induction of nitrate reductase activity and nitrogen fixation in two Phaseolus species in relation to exogenous nitrate level. Physiol. Mol. Biol Plants 4:181-188.

Silveira JAG, Matos JCS, Ceccato VM, Viégas RA, Oliveira JTA(2001a) Nitrate reductase activity, distribuition and response to nitrate in two contrasting Phaseoulus species inoculated with Rhizobium spp. Environ. Exp. Bot. 46:37-46.

Silveira JAG, Melo ARB, Viégas RA, Oliveira JTA (2001b) Salinity-induced effects on nitrogen assimilation related to growth in cowpea plants. Environ. Exp. Bot. 46:171-179.

Sommers DA, Kuo T, Kleinhofs A, Warner RL, Oaks A (1983) Synthesis and degradation of barley nitrate reductase. Plant Physiol. 72:949-952.

Viégas RA, Silveira JAG (1999) Ammonia assimilation and proline accumulation in young cashew plants during long-term exposure to NaCl-salinity. Rev. Bras. Fisiol. Veg. 11:153-159.

Viégas RA, Melo ARB, Silveira JAG (1999) Nitrate reductase activity and proline accumulation in young cashew (Anacardium occidentale L.) plants in response to NaCl-salt shock. Rev. Bras. Fisiol. Veg. 11:21-28. 